\title{
The Role of Corporate Social Responsibility in Supporting Second-Order Social Capital and Sustainable Innovation Ambidexterity
}

\author{
Asif Khan ${ }^{1, *}$, Li-Ru Chen ${ }^{2, *}$ and Chao-Yang Hung ${ }^{3}$ \\ 1 Department of Marketing and Distribution Management, College of Management, National Kaohsiung \\ University of Science and Technology, Kaohsiung 824005, Taiwan \\ 2 Ph.D. Program in Management, Da-Yeh University, Changhua 515006, Taiwan \\ 3 Department of International Business Management, Da-Yeh University, Changhua 515006, Taiwan; \\ cyhung@mail.dyu.edu.tw \\ * Correspondence: khan_asif04@yahoo.com or i108123112@nkust.edu.tw (A.K.); \\ d0233004@cloud.dyu.edu.tw or chen_907@yahoo.com.tw (L.-R.C.)
}

Citation: Khan, A.; Chen, L.-R.; Hung, C.-Y. The Role of Corporate Social Responsibility in Supporting Second-Order Social Capital and Sustainable Innovation Ambidexterity. Sustainability 2021, 13, 6994. https://doi.org/10.3390/ su13136994

Academic Editor: Andrea Pérez

Received: 24 May 2021

Accepted: 18 June 2021

Published: 22 June 2021

Publisher's Note: MDPI stays neutral with regard to jurisdictional claims in published maps and institutional affiliations.

Copyright: (c) 2021 by the authors. Licensee MDPI, Basel, Switzerland. This article is an open access article distributed under the terms and conditions of the Creative Commons Attribution (CC BY) license (https:/ / creativecommons.org/licenses/by/ $4.0 /)$.

\begin{abstract}
This research contributes to the developing literature on CSR, second-order social capital, and sustainable innovation ambidexterity by (1) offering a complete theoretical framework grounded on related theories by clarifying the associations between the four components of CSR proposed by Carroll, because this model suggests a company to be a responsible member of the society by following the required laws while generating profits and conducting philanthropic initiatives, SSC, and sustainable innovation ambidexterity, and (2) testing this framework in a new setting and with a new target population. This study focuses on the top-level management of different manufacturing companies located in Pakistan. A total of 34 manufacturing industries were selected using a cluster sampling technique based on their proximity in the selected cluster. Geographical location and industry type were selected as the criteria to group the industries in clusters. The data collected from 220 top and middle-level managers were analyzed using a partial least square method while the moderation analysis was conducted by using variance analysis. According to the findings of this study, economic, ethical, legal, and philanthropical responsibilities of CSR were all found to have a positive influence on second-order social capital. The economic, ethical, and legal responsibility of CSR did not influence sustainable innovation ambidexterity, whereas the philanthropical responsibility of CSR was found to have a positive influence on sustainable innovation ambidexterity. The findings of this research study will allow the managers to identify the right mix of CSR initiatives required to manage SSC and sustainable innovation exploitation and exploration techniques.
\end{abstract}

Keywords: manufacturing industries; corporate social responsibility (CSR); second-order social capital; sustainable innovation ambidexterity; partial least square

\section{Introduction}

Corporate social responsibility (CSR) is an essential topic of debate for practitioners and researchers. Rajak [1] observes that most international firms have stepped away from utilizing conventional principles, such as corporate generosity and philanthropy, and currently principles such as collaboration, social investment, and empowerment are offered greater significance. An organization is expected to communicate its values and concentrate on its actions to meet the social, economic, legal, and environmental requirements of society. Hence, modern organizations not only embrace corporate social responsibility (CSR) but also utilize CSR programs as critical management initiatives [2]. Furthermore, the implication of CSR has heightened the requirement to operate a company innovatively, deliberately incorporating ecological, economic, and societal concerns in 
activities and approaches of company activity [3]. At present, the significance of CSR cannot be ignored because of the highly competitive environment encountered by the corporations. Therefore, socially responsible conduct is coordinated with people's ethical, moral, and economic beliefs [4]. Hence, general managers of industrial corporations cannot overlook CSR to gauge ecological performance as numerous researchers verified that CSR substantially enhances the performance of an organization [5-7]. Consequently, corporations are expected to fulfill the ethical and social responsibilities rather than utilizing it as a differentiating approach to achieve organizational authenticity [8]. The growing awareness and insight of CSR initiatives have driven CSR activities as a competitive strategy between firms. Carroll's corporate social performance (CSP) model (1979 and 1998) is used in this study to measure CSR. According to this model, CSR has four dimensions, including legal, economic, philanthropic, and ethical. This is a popular model and has been adopted by a large number of practitioners under various circumstances $[8,9]$. Consequently, this model proposes that a firm is accountable for the profit generation of its stakeholders, fulfilling all the legal obligations, conducting activities as a representative of society, and engaging in philanthropic events [10].

Commitment, trust, social contacts, stakeholders' interests, and moral values are concerns related to corporate social responsibility. Hence, the prospects of scholars have been focused both on the linkages among CSR and social capital to explore strategies to enhance the social responsibility of firms and utilize strategies as a possible foundation for the development of social capital [11]. Pierre Bourdieu [12] coined and analyzed the concept of social capital for the first time. According to Bourdieu's findings, two study types appeared, social network theorists analyzed the first type of pattern [13-16]. They emphasized the personal benefits such as career advancement. However, the second pattern is based on taking social capital for the betterment and advancement of societal improvement instead of personal gain [17-19]. Previous studies adapted social capital as first-order SC. Nevertheless, Galunic et al. [20] adapted an actor perspective to demonstrate the existence of second-order social capital (SSC). Thus, the goal of this study is to explore the two study patterns and further develop the concept of SSC. This study defines SSC as the resources and knowledge acquired from the firm's indirect social capital. This concept can be linked to the supply chain. According to supply chain management, suppliers and customers are the firm's social capital. It is found that knowledge from suppliers and customers can impact the innovation of a firm [21,22]. This research study divides SSC into two dimensions. The first one is the SSC acquired from customers and the second one is the SSC acquired from suppliers. A firm adapting second-order social capital based on social exchange theory might have access to resources and knowledge beyond its social network. If the resources and information are acquired from customers it is meant to be second-order social capital from customers, whereas if the resources and information are acquired from suppliers it is meant to be second-order social capital from suppliers [23].

Most of the earlier studies only considered the significance of first-order social capital and overlooked the impact of firms' SSC [24]. The first-order social capital of a firm can acquire a limited amount of resources and knowledge [25]. The significance of second-order social capital should also be considered essential. Normally the resources and knowledge of a firm in a system are relocated to an alternative firm that allocates them to improve their operations with a third firm. Therefore, second-order social capital (SSC) is characterized as the resources and information acquired from indirect social capital. The firm interacts frequently with its suppliers and customers during its operations [26]. We will explore the impact of the four dimensions of Carroll's CSR model on the firm's SSC.

Sustainable innovation is also found to be of significance in maintaining sustainable development due to the high rise in environmental issues and regulations. Sustainable innovation is also found to be accountable for positively influencing the firm's financial, social, and environmental performance; furthermore, it is also useful in solving environmental issues [27]. Nevertheless, only a handful of firms are equipped with the comprehensive knowledge and resources to boost sustainable innovation [23]. Companies are needed to 
hit the correct symmetry between exploration and exploitation to conquer the ambiguity linked with the utilization of exploration practices and the overdependence on the utilization of obsolete practices linked to exploitation separately [28]. As March [29] was the first scholar to adapt the notion of "ambidexterity" in the framework of innovation, proposing exploration and exploitation, several practitioners explored exploratory and exploitative innovation [19,30,31]. If the process enhances the firm's current knowledge, it is known to be exploitative innovation. Hence, the goal of exploitative innovation is to upgrade the current resources or technologies. On the contrary, exploratory innovation is to acquire novel and distinct knowledge and intelligence to coordinated systems [19,30]. As a result, exploratory innovation improves its existing knowledge and creates innovative resources or information. Therefore, some firms are exploring resources and information related to sustainable innovation beyond their firm [31]. Earlier studies have investigated the impact of ambidexterity in organizations with numerous major matters such as uncovering the latest data, boosting the company's performance, devising innovative products, and supply chain management [28].

To fill these research gaps, we examine Carol's CSP model of CSR to investigate the impact of economic, legal, ethical, and philanthropical responsibilities on sustainable innovation ambidexterity and SSC capital having two dimensions (i.e., SSC from customers and SSC from suppliers). Based on the research gaps noted, we approach the following two questions. First, do the four constructs of CSR support second-order social capital? Second, do the four constructs of CSR have a positive influence on second-order social capital?

The study tends to contribute to the developing literature on CSR, second-order social capital, and sustainable innovation ambidexterity by (1) offering a complete theoretical framework grounded on related theories by clarifying the associations between the four components of CSR, with SSC, and sustainable innovation ambidexterity, and (2) testing this framework in a new setting and with a new target population-senior managers of firms in Pakistan.

\section{Literature Review}

\subsection{Corporate Social Responsibility and Second-Order Social Capital}

CSR is defined as the activities conducted by a firm to acquire sustainable results by engaging in issues related to the economic, ethical, legal, and philanthropical impacts created by its initiatives [32]. An additional essential component of CSR is to make sure that the firm's regulations and operations are formulated and conveyed clearly and indicate corporate responsibility to guarantee decent results for society as a unit. CSR integrates the firm to all the stakeholders, to both the global and local economy, and to the theories of voluntarism and sustainability. According to Porter and Kramer [33], a firm's CSR activities are indicated as a component that can improve a firms' competitive advantage. In this research study, the four dimensions of Carroll's CSP model (1998) were adopted, which indicate that (a) the economic component involves delivering a return on investment for stakeholders, generating jobs, and compensating workforces with reasonable salaries, exploring novel resources, and endorsing the formation of state-of-the-art products and services; (b) the legal component includes fulfilling legal obligations; (c) the ethical component comprises avoiding ethical standards from getting compromised to attain firm's objectives and avoiding societal damage; and $(\mathrm{d})$ the philanthropic component incorporates actively engaging in charitable and voluntary contributions, delivering aid to educational institutes, and supporting volunteer schemes to improve the society's quality of life [9]. Carroll revised his initial CSP model and proposed a pyramid concept (1991). In this pyramid, the economic dimension is located at the bottom, legal, ethical, and philanthropic dimensions were found to be the third, second, and top layers, respectively. According to the pyramid, Windsor [34] proposed that legal and economic dimensions are essential within society, whereas ethical dimension is anticipated within society, and philanthropic dimension is needed within society. 
The concept of social capital originates from the assumption that individuals who are engaged in dealings with each other ultimately establish relationships that can endure over time, up to a certain level. It is feasible to utilize these practices of "stored" relationships in several methods, for instance, to obtain knowledge that both sides perceive as beneficial or to locate a resource of material or moral assistance [35]. Although "social capital" initially surfaced in the literature related to civic studies, the area of studies related to business was swift to implement it, too [36]. Although a firm's first-order social capital can acquire information and resources beyond the firm, the information and resources are still considered to be inadequate [25]. SSC is built on the social exchange theory and according to this theory, a firm can gain resources and information beyond its social network. In this research, SSC is divided into two components: SSC from suppliers because of the firm's frequent interactions with suppliers and SSC from customers because of the firms' recurrent communications with its customers. The rationality of this viewpoint can be observed in a supply chain. In supply chain management, suppliers and customers are the social capital of a firm. It is analyzed that knowledge from suppliers and customers impact the growth and invention capabilities of a firm [21-23,37,38].

According to the findings of Vveinhardt et al. [39], social accountability in the area of social capital is recognized as a value of shareholders' ethical and resource capital, established via shared trust, which must be extended in the enhancement of shareholders' commitment and trust. Shareholders' ethical beliefs and morals have a significant influence on the growth of both SC and CSR. Furthermore, Weisband [40] also highlighted that social capital has an essential impact on shareholders and offers opportunities to resolve challenges mutually. Antoni and Portale [41] asserted that the execution of good corporate social responsibility procedures in various firms is substantial in defining its outcome on employees' social capital. Additionally, Cesar and Jhony [11] added that social capital and CSR in cooperation develops mutual commitment, socialization, and trust among the firm shareholders and managers; establishes the stability of the economic performance in the market according to the legal obligations; enhances and develops understanding among commercial and public firms; ensures implementation of the basic ethical norms in relationships between competitors, consumers, and partners; decreases expenses; fosters agreement inside the firm; improves human resource; and broadens knowledge on the ways to interact in the market. Thus, there exists a relationship between CSR and SC [39]. We recommend the following four hypotheses.

Hypothesis 1a (H1a). Economic responsibility (CSR) positively influences second-order social capital.

Hypothesis $\mathbf{1 b} \mathbf{( H 1 b ) . ~ L e g a l ~ r e s p o n s i b i l i t y ~ ( C S R ) ~ p o s i t i v e l y ~ i n f l u e n c e s ~ s e c o n d - o r d e r ~ s o c i a l ~ c a p i t a l . ~}$

Hypothesis 1c (H1c). Ethical responsibility (CSR) positively influences second-order social capital.

Hypothesis 1d (H1d). Philanthropical responsibility (CSR) positively influences second-order social capital.

\subsection{Corporate Social Responsibility and Sustainable Innovation Ambidexterity}

Recently, researchers focused specifically on CSR as customers need environment friendly services and products. The phrase eco-entrepreneur utilizes that aim to safeguard and avoid environmental problems amongst several businesses and to establish ecofriendly products and practices inside the market [42]. Numerous firms have encountered pressure from firms' shareholders, for instance, customers, competitors, government, and workers to express societal and ecological concerns [43]. Recently, CSR has been deemed a substantial business strategy worldwide [44]. Furthermore, there is much research obtainable on CSR; however, there is no specific description of CSR. Consequently, research scholars encountered complexity in doing such an empirical study. Firms are required to operate 
according to common public beliefs to be successful. Additionally, firms that are inwardly concentrated possess limited durability, while firms that are more concerned regarding their customers are prone to be successful in the existing marketplace. CSR describes the responsibility of a firm to engage in those tactics, sticking to those objectives that create value for the common public [6].

Carroll's (1979 and 1998) model of CSP has been commonly used in corporate social responsibility research [45]. This is a four-dimensional model that gauges a firm's noneconomic responsibility, in conditions of its ethical, philanthropic, and legal impacts on society. In other words, this model incorporates economic issues and results in a societal performance structure, and offers users a beginning point for successful CSR [9].

A few years ago, business experts, ecological legislators, scholars, and entrepreneurs did not consider the ecosystem because they considered that products produced in their companies did not have a considerable impact on the ecosystem. Ecological deterioration has turned out to be a global challenge. Nevertheless, currently, business specialists, ecological representatives, businessmen, and academics approve that the grounds of ecological decline consist of climate change, increasing air and water contamination, air discharges, resource reduction, and utilization of hazardous substances [6]. We propose exploratory and exploitative innovation in the area of environmental safety and ecofriendly advancement, recommending sustainable exploratory innovation and sustainable exploitative innovation in this study. Sustainable exploitative innovation implies that a business enhances an existing product or expertise, making it ecologically friendly. Nevertheless, sustainable exploratory innovation implies a business creates a novel ecological safety product or technology.

Due to numerous ecological problems that have been stated, businesses ought to focus on ecological and nature preservation responsibilities. Considering "sustainable" matters has been a major motivation for business experts and academics in the past few years $[46,47]$. In sustainable innovation, recombination means utilizing its current sustainable expertise or knowledge combinations to build new environmentally friendly technology or product, associated with the sustainable exploitative innovation of the firm. However, novel combination implies the usage of sustainable information or information of the firm that has never been combined before covering its new or current sustainable information, the grouping of current ones is related to sustainable exploitative innovation, while the grouping of novel ones is related to sustainable exploratory innovation. Based on a theoretical perspective, various scholars acknowledge the presence of a correlation between CSR and innovation [48]. However, there is inadequate research conducted that measures the impact of corporate social responsibility on innovation [49]. Research scholars have overlooked exploring sustainable innovation ambidexterity through CSR. Therefore, this research tries to fulfill this research gap by hypothesizing as follows:

Hypothesis 2a (H2a). Economic responsibility (CSR) positively influences sustainable innovation ambidexterity.

Hypothesis $\mathbf{2 b} \mathbf{( H 2 b )}$. Legal responsibility (CSR) positively influences sustainable innovation ambidexterity.

Hypothesis 2c (H2c). Ethical responsibility (CSR) positively influences sustainable innovation ambidexterity.

Hypothesis $\mathbf{2 d} \mathbf{( H 2 d )}$. Philanthropical responsibility (CSR) positively influences sustainable innovation ambidexterity.

The research framework indicating the relationships between the research constructs have been highlighted in Figure 1. 


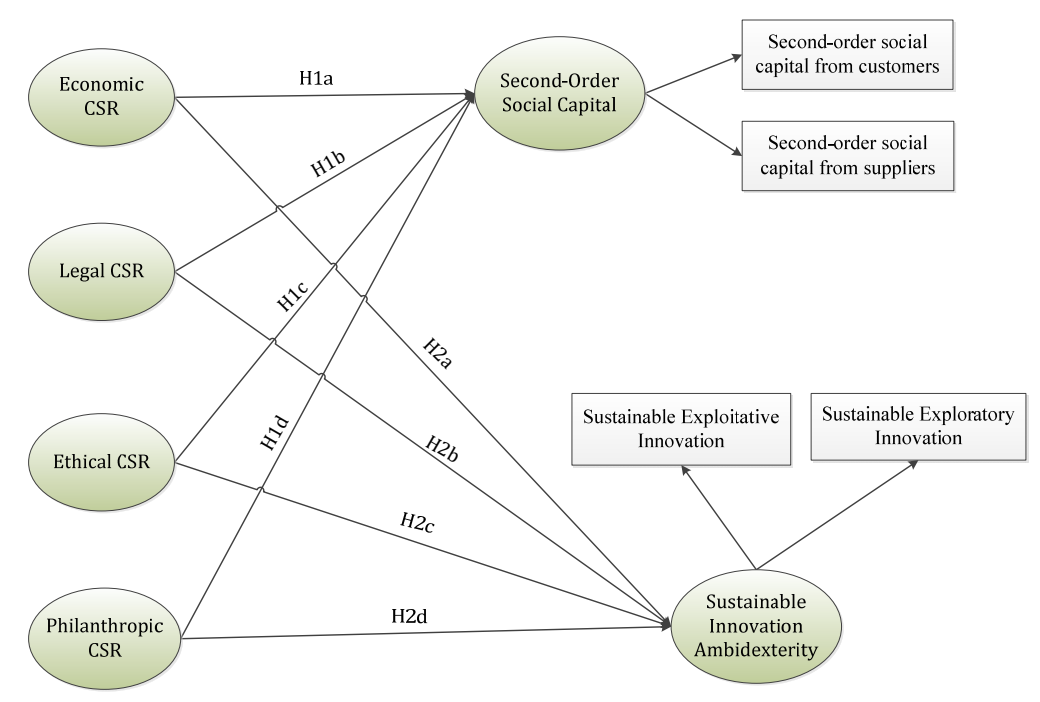

Figure 1. Research framework.

\section{Methodology}

Sample and Procedure

The data for this research were gathered from manufacturing companies in Pakistan to which less interest has been given regarding corporate social responsibility, sustainable innovation, or social capital [50,51]. This study focuses on the top-level management of different manufacturing companies located in Pakistan. A total of 34 manufacturing industries were selected using a cluster sampling technique based on their proximity in the selected cluster. The industries were divided into clusters based on their geographical location and industry type. The data for the survey were gathered from various manufacturing industries, to eradicate the disparities between industries. These companies were selected from the Punjab and KP provinces of Pakistan. These provinces signify distinct environments of market economy and manufacturing advancement; hence, they were more suitable. Islamabad is the capital of the country; hence, it signifies a higher degree of economic growth in Pakistan, whereas Peshawar is in the northwest of the country, indicating an average level of economic growth. By choosing samples from diverse geographical areas, the possible effect of regional biases was reduced [23]. Islamabad and Peshawar are the capital cities of Punjab and KP, and they were chosen based on their significance and geographical proximity. The sample included manufacturing SMEs operational in various industries such as textiles, FMCG, and shoes, etc. Manufacturing industries in the industrial zones of Peshawar and Islamabad were selected in this research. A close-ended self-administered questionnaire was distributed to the top management of manufacturing firms. Instead of requesting respondents merely whether they approve or agree to a statement, Likert scale components queried how firmly they approve or oppose it, normally on a 7-point scale from 1 (= strongly disagree) to 7 (= strongly agree), with 4 associating to a neutral category.

A pretest was conducted by a sample of 30 top-level managers among five manufacturing firms located in Peshawar city. Corporate social responsibility was measured by items suggested by [52] while the items to measure second-order social capital and sustainable innovation ambidexterity were adopted from Zhao et al.'s research [23]. The hypothesis of this study was tested using a partial least square method.

\section{Results}

\subsection{Data Analysis}

Two methods of assessing and evaluating partial least squares (PLS) were performed. In the preliminary phase, the authenticity and reliability evaluation were performed, whereas, in the next phase, the descriptive capability of the structural framework was examined and evaluated. The objective of the two phases stated before was to verify the con- 
struct's reliability and validity, including checking the link between the constructs $[53,54]$. PLS has been applied and deemed as the finest instrument for explaining the underlying collaboration among variables and thus can simultaneously manage framework variables and measurement objects [55]. Moreover, as PLS has easier boundaries for variable normalcy and uncertainty; it is perfect for examining the association when the variables are irregularly distributed. It has the advantage of assessing dynamic estimate models [56]. PLS was hence more appropriate for this study than previous SEM evaluation methods to assess the relations between constructs, reduce measurement inaccuracies, and prevent collinearity.

According to previous studies, companies use the knowledge from suppliers to boost sustainable exploitative innovation and knowledge from customers to stimulate sustainable exploratory innovation. Knowledge from suppliers is used by companies under its existing methods, programs, resources [4], product design, and product functions; hence, it is essential for a company to build sustainable innovation [5]. Furthermore, knowledge from customers is utilized by companies to gain insights regarding the preferences of customers; it is related to a new concept concerning the product plan or production procedure. This information also assists companies with the precise ultimate needs of customers. Hence, it facilitates companies to determine the nature of sustainable innovation [6]. Nevertheless, in the completion of sustainable innovation, companies do not entirely get external knowledge, which sometimes precedes the failure of sustainable innovation. Consequently, companies must consider second-order social capital during implementation of sustainable innovation.

\subsection{Convergent and Discriminant Validity}

The structural equation modeling (SEM) method is applied to analyze the anticipated hypotheses established in the previous section of this study, and therefore, the Smart PLS 3.2.8 was used. Hair et al. [57], states that the partial least square structural equation modeling (PLS-SEM) technique is very appropriate for simple and complicated models. Likewise, the research scholars determined that PLS-SEM is a viable technique for assessment in comparison to CB-SEM. There are several grounds to conduct PLS-SEM. For instance, PLS-SEM is deemed well in processing and analyzing estimations in comparison to regression for calculating mediation [58]. Furthermore, research scholars verify that while applying PLS-SEM the verification of the normality assumption is not required [57].

Our theoretical framework comprises six constructs, where economic, legal, ethical and philanthropical are the first-order constructs having several dimensions each, and they are used to measure corporate social responsibility. This study also contains two secondorder constructs. The first is second-order social capital having two constructs, SSC from customers and suppliers, whereas the second one is sustainable innovation ambidexterity containing two constructs, sustainable exploratory and exploitative innovation.

PLS-SEM includes both the inner and outer models. Three types of tests, including convergent validity, discriminant validity, and individual item reliability, are used to measure the reflective constructs of the outer model. According to Table 1, the highest factor loading value is 0.855 , while the lowest factor loading is 0.673 , which is found to be higher than the proposed threshold value of 0.50 (Hair et al. 2014). These findings prove that this research has no issues related to individual item reliability. Research scholars can hold the item possessing the factor loading higher than 0.40 and lower than 0.50 , if the item is not affecting the average variance extracted (AVE) and composite reliability (CR). The CR of every variable is computed by measuring the internal consistency reliability. Hair et al. [57] indicated that the CR value must be greater than 0.60 . The CR value of each construct is greater than 0.60 , demonstrating internal consistency, reliability, and homogeneity, see Table 1 [59]. This research shows that the internal consistency principle is met. Convergent validity implies the extent to which that item of variables analyzes a similar construct. According to the findings indicated in Tables 1 and 2, the highest value of AVE is found to be 0.671 , whereas the lowest value of AVE is 0.548 . Consequently, this 
research satisfies the convergent validity principle, as suggested by Hair et al. [57] who state that the value of AVE should be greater than or equal to 0.50 .

Table 1. Convergent validity for first-order constructs.

\begin{tabular}{|c|c|c|c|c|c|}
\hline Construct & Item Code & Factor Loading & Cronbach's Alpha & $\begin{array}{l}\text { Composite } \\
\text { Reliability }\end{array}$ & $\begin{array}{l}\text { Average Variance } \\
\text { Extracted (AVE) }\end{array}$ \\
\hline \multirow{4}{*}{ Economic CSR } & Eco1 & 0.742 & \multirow{4}{*}{0.864} & \multirow{4}{*}{0.865} & \multirow{4}{*}{0.615} \\
\hline & Eco2 & 0.789 & & & \\
\hline & Eco3 & 0.789 & & & \\
\hline & Eco4 & 0.815 & & & \\
\hline \multirow{3}{*}{ Legal CSR } & Leg1 & 0.813 & \multirow{3}{*}{0.796} & \multirow{3}{*}{0.797} & \multirow{3}{*}{0.569} \\
\hline & Leg2 & 0.770 & & & \\
\hline & Leg3 & 0.673 & & & \\
\hline \multirow{3}{*}{ Ethical CSR } & Ethi1 & 0.696 & \multirow{3}{*}{0.825} & \multirow{3}{*}{0.821} & \multirow{3}{*}{0.607} \\
\hline & Ethi2 & 0.778 & & & \\
\hline & Ethi3 & 0.855 & & & \\
\hline \multirow{3}{*}{ Philanthropical CSR } & Phi1 & 0.803 & \multirow{3}{*}{0.802} & \multirow{3}{*}{0.801} & \multirow{3}{*}{0.575} \\
\hline & Phi2 & 0.790 & & & \\
\hline & Phi3 & 0.675 & & & \\
\hline \multirow{6}{*}{$\begin{array}{c}\text { SEP (Sustainable } \\
\text { Exploratory Innovation) }\end{array}$} & SEP1 & 0.794 & \multirow{6}{*}{0.925} & \multirow{6}{*}{0.924} & \multirow{6}{*}{0.671} \\
\hline & SEP2 & 0.755 & & & \\
\hline & SEP3 & 0.766 & & & \\
\hline & SEP4 & 0.802 & & & \\
\hline & SEP5 & 0.809 & & & \\
\hline & SEP6 & 0.800 & & & \\
\hline \multirow{5}{*}{$\begin{array}{c}\text { SET (Sustainable } \\
\text { Exploitative Innovation) }\end{array}$} & SET1 & 0.769 & \multirow{5}{*}{0.892} & \multirow{5}{*}{0.892} & \multirow{5}{*}{0.623} \\
\hline & SET2 & 0.782 & & & \\
\hline & SET3 & 0.759 & & & \\
\hline & SET4 & 0.779 & & & \\
\hline & SET5 & 0.787 & & & \\
\hline \multirow{8}{*}{$\begin{array}{l}\text { SOCC (Second-order } \\
\text { Social Capital from } \\
\text { Customers) }\end{array}$} & SOCC1 & 0.699 & \multirow{8}{*}{0.905} & \multirow{8}{*}{0.906} & \multirow{8}{*}{0.548} \\
\hline & SOCC2 & 0.743 & & & \\
\hline & SOCC3 & 0.741 & & & \\
\hline & SOCC4 & 0.763 & & & \\
\hline & SOCC5 & 0.778 & & & \\
\hline & SOCC6 & 0.745 & & & \\
\hline & SOCC7 & 0.657 & & & \\
\hline & SOCC8 & 0.651 & & & \\
\hline & SOSS1 & 0.720 & & & \\
\hline SUSS (Second-order Social & SOSS2 & 0.779 & 0.822 & 0.824 & 0.610 \\
\hline & SOSS3 & 0.800 & & & \\
\hline
\end{tabular}

Table 2. Convergent validity for second-order constructs.

\begin{tabular}{cccccc}
\hline Construct & Item Code & Factor Loading & $\begin{array}{c}\text { Cronbach's } \\
\text { Alpha }\end{array}$ & $\begin{array}{c}\text { Composite } \\
\text { Reliability }\end{array}$ & $\begin{array}{c}\text { Average Variance } \\
\text { Extracted (AVE) }\end{array}$ \\
\hline $\begin{array}{c}\text { Sustainable Innovation } \\
\text { Ambidexterity (Second Order) }\end{array}$ & SEP & 0.819 & 0.945 & 0.945 & 0.612 \\
\hline $\begin{array}{c}\text { Second-order Social Capital } \\
\text { (Second Order) }\end{array}$ & SOCC & 0.790 & 0.740 & 0.928 & 0.541 \\
\hline
\end{tabular}

The level of discrimination between testing variables and numerous construct criteria is identified by discriminatory validity. Table 3 indicates a fair discriminant validity for each indicator when the loading factor of each item in the specified latent structure exceeds the loading factor of any other structure [60]. 
Table 3. Standardized factor loadings and cross-loadings of the outer model. (Source: this study, imported from SMART PLS).

\begin{tabular}{|c|c|c|c|c|c|c|c|c|}
\hline & ECO & ETHI & LEG & PHI & GEP & GET & SOCC & SOSC \\
\hline Eco1 & 0.742 & 0.499 & 0.697 & 0.756 & 0.454 & 0.596 & 0.790 & 0.593 \\
\hline Eco2 & 0.789 & 0.556 & 0.766 & 0.753 & 0.526 & 0.577 & 0.850 & 0.633 \\
\hline Eco3 & 0.789 & 0.631 & 0.733 & 0.718 & 0.501 & 0.550 & 0.847 & 0.691 \\
\hline Eco4 & 0.815 & 0.657 & 0.810 & 0.739 & 0.491 & 0.566 & 0.879 & 0.692 \\
\hline Ethi1 & 0.535 & 0.696 & 0.613 & 0.606 & 0.430 & 0.391 & 0.677 & 0.765 \\
\hline Ethi2 & 0.554 & 0.778 & 0.715 & 0.713 & 0.507 & 0.431 & 0.688 & 0.903 \\
\hline Ethi3 & 0.655 & 0.855 & 0.645 & 0.773 & 0.687 & 0.579 & 0.681 & 0.960 \\
\hline Leg1 & 0.833 & 0.668 & 0.813 & 0.717 & 0.529 & 0.557 & 0.897 & 0.705 \\
\hline Leg2 & 0.741 & 0.614 & 0.770 & 0.762 & 0.484 & 0.563 & 0.832 & 0.674 \\
\hline Leg3 & 0.579 & 0.628 & 0.673 & 0.589 & 0.436 & 0.471 & 0.730 & 0.641 \\
\hline Phi1 & 0.733 & 0.771 & 0.733 & 0.803 & 0.593 & 0.562 & 0.758 & 0.973 \\
\hline Phi2 & 0.800 & 0.647 & 0.741 & 0.790 & 0.612 & 0.732 & 0.776 & 0.718 \\
\hline Phi3 & 0.606 & 0.623 & 0.604 & 0.675 & 0.590 & 0.583 & 0.629 & 0.661 \\
\hline SEP1 & 0.553 & 0.605 & 0.504 & 0.661 & 0.835 & 0.755 & 0.556 & 0.620 \\
\hline SEP2 & 0.454 & 0.545 & 0.508 & 0.603 & 0.909 & 0.707 & 0.485 & 0.605 \\
\hline SEP3 & 0.510 & 0.534 & 0.554 & 0.606 & 0.877 & 0.700 & 0.539 & 0.573 \\
\hline SEP4 & 0.513 & 0.628 & 0.533 & 0.655 & 0.893 & 0.710 & 0.545 & 0.669 \\
\hline SEP5 & 0.529 & 0.587 & 0.535 & 0.683 & 0.899 & 0.737 & 0.544 & 0.665 \\
\hline SEP6 & 0.528 & 0.556 & 0.524 & 0.657 & 0.905 & 0.778 & 0.533 & 0.624 \\
\hline SET1 & 0.522 & 0.499 & 0.582 & 0.633 & 0.705 & 0.876 & 0.555 & 0.551 \\
\hline SET2 & 0.559 & 0.480 & 0.554 & 0.636 & 0.734 & 0.930 & 0.558 & 0.532 \\
\hline SET3 & 0.510 & 0.468 & 0.546 & 0.616 & 0.753 & 0.895 & 0.528 & 0.515 \\
\hline SET4 & 0.668 & 0.443 & 0.545 & 0.679 & 0.659 & 0.857 & 0.612 & 0.524 \\
\hline SET5 & 0.616 & 0.501 & 0.557 & 0.693 & 0.676 & 0.868 & 0.604 & 0.537 \\
\hline SOCC1 & 0.873 & 0.499 & 0.697 & 0.756 & 0.454 & 0.596 & 0.790 & 0.593 \\
\hline SOCC2 & 0.924 & 0.556 & 0.766 & 0.753 & 0.526 & 0.577 & 0.850 & 0.633 \\
\hline SOCC3 & 0.911 & 0.631 & 0.733 & 0.718 & 0.501 & 0.550 & 0.847 & 0.691 \\
\hline SOCC4 & 0.916 & 0.657 & 0.810 & 0.739 & 0.491 & 0.566 & 0.879 & 0.692 \\
\hline SOCC5 & 0.833 & 0.668 & 0.962 & 0.717 & 0.529 & 0.557 & 0.897 & 0.705 \\
\hline SOCC6 & 0.741 & 0.614 & 0.957 & 0.762 & 0.484 & 0.563 & 0.832 & 0.674 \\
\hline SOCC7 & 0.579 & 0.628 & 0.900 & 0.589 & 0.436 & 0.471 & 0.730 & 0.641 \\
\hline SOCC8 & 0.535 & 0.949 & 0.613 & 0.606 & 0.430 & 0.391 & 0.677 & 0.765 \\
\hline SOSS1 & 0.554 & 0.976 & 0.715 & 0.713 & 0.507 & 0.431 & 0.688 & 0.903 \\
\hline SOSS2 & 0.655 & 0.909 & 0.645 & 0.773 & 0.687 & 0.579 & 0.681 & 0.960 \\
\hline SOSS3 & 0.733 & 0.771 & 0.733 & 0.942 & 0.593 & 0.562 & 0.758 & 0.973 \\
\hline
\end{tabular}

Notes: ECO CSR = Economic CSR; ETHI CSR = Ethical CSR; LEG CSR = Legal CSR; PHI CSR = Philanthropic CSR; SEP = Sustainable Exploratory Innovation; SET = Sustainable Exploitative Innovation SOSS = Second-order Social Capital from Customers; SOSS = Second-order Social Capital from Suppliers. 
This research followed Tenenhaus et al. [61] to measure the Goodness of Fit (GOF) to explain the overall quality of the framework developed, calculated as follows:

$$
G O F=\sqrt{\overline{A V E}} \times \sqrt{\overline{R^{2}}}=\sqrt{0.586 \times 0.618}=0.601
$$

According to the abovementioned outcome, the GOF is 0.637 , which reaches the 0.36 cutoff criteria for a large impact size [62].

\subsection{Empirical Results}

Smart PLS 3.2.8 was used for estimation of the research model and testing structural path analysis of the hypotheses. In this section, the inner model or structural model is executed. Researchers compute the $p$-values and $t$-values to test the proposed hypotheses in the inner model. The proposed hypotheses are accepted if the $p$-value is lower than 0.05 or the $\mathrm{t}$-value is higher than 1.96.

According to the findings of this study, as indicated in Table 4 and Figure 2, economic, ethical, legal and philanthropical responsibilities of CSR were all found to have a positive influence on second-order social capital supporting H1a $(\beta=0.399$, t-value $=25.209)$, H1b $(\beta=0.324, t-v a l u e=18.481)$, H1c $(\beta=0.304$, t-value $=18.845)$, and H1d $(\beta=0.088$, $\mathrm{t}$-value $=9.764)$.

Table 4. Hypothesis results.

\begin{tabular}{lcccc}
\hline \multicolumn{1}{c}{ Hypothesis } & Path Coefficient & t-Values & $p$-Values & Results \\
\hline H1a-ECO-> Second-Order Social Capital & 0.399 & 25.209 & 0.000 & Supported \\
\hline H1b-ETHI-> Second-Order Social Capital & 0.324 & 18.481 & 0.000 & Supported \\
\hline H1c-LEG-> Second-Order Social Capital & 0.304 & 18.845 & 0.000 & Supported \\
\hline H1d-PHI-> Second-Order Social Capital & 0.088 & 9.764 & 0.000 & Supported \\
\hline H2a-ECO-> Sustainable Innovation Ambidexterity & 0.093 & 1.029 & 0.304 & Not Supported \\
\hline H2b-ETHI-> Sustainable Innovation Ambidexterity & 0.122 & 1.272 & 0.203 & Not Supported \\
\hline H2c-LEG-> Sustainable Innovation Ambidexterity & 0.065 & 0.683 & 0.495 & Not Supported \\
\hline H2d-PHI-> Sustainable Innovation Ambidexterity & 0.512 & 5.753 & 0.000 & Supported \\
\hline
\end{tabular}

Notes: ECO CSR = Economic CSR; ETHI CSR = Ethical CSR; LEG CSR = Legal CSR; PHI CSR = Philanthropic CSR.

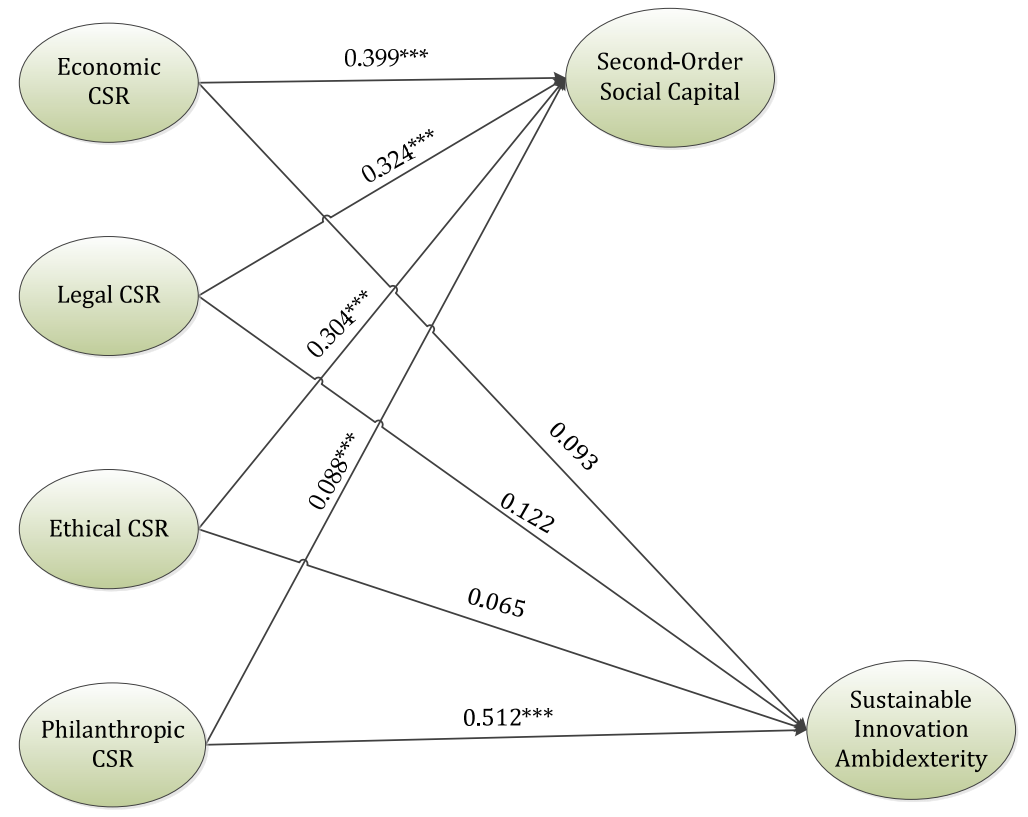

Figure 2. A framework of the inner model result. Note: ${ }^{* *} p$-value $<0.001$. 
The economic, ethical, and legal responsibility of CSR do not influence sustainable innovation ambidexterity, therefore $\mathrm{H} 2 \mathrm{a}(\beta=0.093, \mathrm{t}$-value $=1.029), \mathrm{H} 2 \mathrm{~b}(\beta=0.122$, $\mathrm{t}$-value $=1.270)$, and $\mathrm{H} 2 \mathrm{c}(\beta=0.065$, $\mathrm{t}$-value $=0.683)$ are not supported. Philanthropical responsibility of CSR is found to have a positive influence on sustainable innovation ambidexterity $(\beta=0.512$, $\mathrm{t}$-value $=5.753)$, thus $\mathrm{H} 2 \mathrm{~d}$ is supported.

\section{Discussion and Conclusions}

This paper aimed to observe the relationship between Carrol's four dimensions of CSR with SSC and sustainable innovation ambidexterity. This study created a conceptual model that analyzed whether CSR initiatives supported sustainable innovation ambidexterity and SSC based on Carroll's CSP model (1979; 1998), Social Capital Theory, and Social Exchange Theory [63]. This research offered a framework to describe in what way the four CSR dimensions influenced the SSC and sustainable exploratory and exploitative strategies of firms operating in the industrial areas of Pakistan. This framework will assist more research scholars to identify the firms' behaviors toward sustainable innovation ambidexterity and second-order social capital built on their views of four dimensions of CSR.

The results related to the various impacts of the four CSR dimensions on secondorder social capital revealed a distinctive CSR phenomenon within the firms located in the industrial zones of Pakistan. If senior management of the firms perceives that the firm has employed economic, legal, philanthropic, and ethical CSR programs, their views of the benefits related to second-order social capital will be influenced positively. Of the four CSR dimensions, the economic dimension was discovered to be the most crucial in affecting a firm's second-order social capital. The results of this study are somewhat similar to a research study conducted in Peru by Cesar and Jhony [11]. That research study aimed to target the mining industry in Peru and analyze the association between CSR and SC. A qualitative analysis was conducted and a framework having four quadrants was demonstrated as a result of this study. The framework suggested the appropriate use of the CSR initiatives, which can move negative CSR to positive CSR and produce a strong SC as well.

However, according to the findings related to the second research gap of this research study, the legal, economic, and ethical dimensions of CSR were uncovered to be in an insignificant relationship with sustainable innovation ambidexterity, although only the philanthropic dimension was found to have a significant direct impact on sustainable innovation ambidexterity. These results reveal that the philanthropic CSR dimension is the crucial factor for the firms to get the benefits from second-order social capital. Benevolence and righteousness, which are the fundamental principles of Confucianism, relate perfectly to the philanthropic dimension. Therefore, it is probable that the target sample of this research, who might be inspired by Confucianism, optimistically answered to the firm's philanthropic programs, which enhances the self-image of the target sample through association with the firm engaged in these kinds of programs [9].

Literature available on corporate social responsibility and innovation is limited [49]. However, the results are similar to a study by Kraus et al. [6]. In this study, they utilized three dimensions of CSR (economic dimension, environmental dimension, and social dimension) by Hernández et al. [3]. This research explores the impact of CSR on environmental performance. Their findings demonstrated a positive association between CSR and sustainable innovation; furthermore, sustainable innovation was found to be a significant mediator between corporate social responsibility and environmental performance.

\section{Theoretical Implications}

Theoretical contribution involves certain types of discoveries of the study that can offer new perceptions about a phenomenon that is considered vital for enhancing organizational significance. This research presents an innovative insight centered on the empirical analysis of CSR, SSC, and sustainable innovation ambidexterity. It thus adds by determining the relationship of CSR with SSC and sustainable innovation ambidexterity. 
This study also contributes to the current information system of SSC and sustainable innovation ambidexterity. It boosts our knowledge regarding the importance of social capital by improving the social capital theory and social exchange theory. Furthermore, it analyzes the effects of the four dimensions of Carell's CSR model on the two dimensions of SSC, including SSC from customers and SSC from suppliers, and on sustainable innovation ambidexterity.

This study contributes to sustainable innovation by including sustainable exploratory innovation and sustainable exploitative innovation as two dimensions of sustainable innovation.

Henceforth, our research makes noteworthy contributions as ground-breaking research that incorporates corporate social responsibility (economic, legal, ethical, and philanthropical), second-order social capital (SSC from customers and SSC from suppliers), and sustainable innovation ambidexterity (sustainable exploratory innovation and sustainable exploitative innovation) in a single research model. Earlier research scholars employed stakeholder theory, Pierre Bourdieu's theory [12], and ability motivation-opportunity theory, to measure CSR, social capital, and sustainable innovation [3]. The theory of social capital was thoroughly examined first by Pierre Bourdieu [12]. This study enriches social exchange theory and uses second-order social capital instead of the traditional first-order social capital. This research adds to existing literature by examining the association between CSR, SSC, and sustainable innovation in light of Carrol's CSR model, social capital theory, and social exchange theory. This research extended studies on the role of CSR in supporting second-order social capital and sustainable innovation ambidexterity in the manufacturing industry. Furthermore, this research recognizes in what way manufacturing firms can manage their CSR, for achieving SSC and sustainable innovation ambidexterity.

\section{Practical Implications}

The results of this study propose major implications for business professionals and general managers. The research framework of this study seeks to extend direction for manufacturing businesses concerning the impact of CSR strategies on SSC and sustainable innovation ambidexterity.

This study suggests that firms trying to enhance second-order social capital must provide significance to CSR activities. SSC from customers can help firms to acquire precise information regarding the needs and preferences of customers [22]. In contrast, SSC from suppliers can assist the firm in acquiring information regarding environmental safety technologies and new materials [64].

Second, based on the findings of this research, the policymakers or general managers of the firms can direct their energies on philanthropic initiatives such as introducing a range of volunteer events, social wellbeing schemes, and education plans for the community's youth to enhance sustainable innovation ambidexterity. Additionally, to enhance the sustainable innovation ambidexterity, they can highlight philanthropic CSR activities by forming regulations for the firm's activities, trying to eliminate irregularities, and ensuring fair treatment of all their stakeholders. Thus, this research can benefit firms by successfully distributing their funds in CSR initiatives. The results also indicate that firms should focus on enhancing their CSR activities because all four dimensions of CSR not only directly influence second-order social capital, but the philanthropic dimension also has a significant impact on sustainable innovation ambidexterity. To enhance and gauge SSC and sustainable innovation ambidexterity, policymakers and general managers must make efforts on CSR.

\section{Limitations and Future Research}

Similar with earlier studies, this research also has a few limitations, which future scholars can work out. This research used the cross-sectional approach and hence researchers are not certain whether CSR, SSC, and sustainable innovation ambidexterity in manufacturing firms will be able to deliver identical results in a longer period. Therefore, upcoming research scholars can adapt this research framework to examine whether 
the results would change or would remain the same over longer periods. This research gathered data from manufacturing firms located in industrial zones of Pakistan using a cluster sampling approach. Upcoming researchers can gather data from firms located in other developed countries to see the changes in results. This research does not further examine the intermediary process. There is a possibility of having mediators that can operate as intermediaries in the relationship of CSR and sustainable innovation. Future researchers can also use second-order social capital as a mediating construct between CSR and sustainable innovation ambidexterity. This can help us recognize the advantages and risks associated with second-order social capital. Furthermore, circular economy standards can be utilized to define economic, environmental, and social performance [65].

Author Contributions: Conceptualization, A.K., L.-R.C. and C.-Y.H.; Formal analysis, A.K. and L.-R.C.; Investigation, A.K.; Methodology, A.K., L.-R.C., and C.-Y.H.; Validation, L.-R.C. and C.-Y.H.; Writing-original draft, A.K., L.-R.C. and C.-Y.H.; Writing-review \& editing, A.K., L.-R.C. and C.-Y.H. All authors have read and agreed to the published version of the manuscript.

Funding: This research received no external funding.

Informed Consent Statement: Informed consent was obtained from all subjects involved in the study.

Conflicts of Interest: The authors declare no conflict of interest.

\section{References}

1. Rajak, D. “Uplift and empower”: The market, morality and corporate responsibility on South Africa's platinum belt. In Hidden Hands in the Market: Ethnographies of Fair Trade, Ethical Consumption, and Corporate Social Responsibility; Emerald Group Publishing Limited: Bingley, UK, 2008.

2. Bielak, D.; Bonini, S.M.; Oppenheim, J.M. CEOs on strategy and social issues. McKinsey Q. 2007, 4, 1-8.

3. Hernández, J.P.S.-I.; Yañez-Araque, B.; Moreno-García, J. Moderating effect of firm size on the influence of corporate social responsibility in the economic performance of micro-, small-and medium-sized enterprises. Technol. Forecast. Soc. Chang. 2020, 151, 119774. [CrossRef]

4. O'Connor, A.; Shumate, M.; Meister, M. Walk the line: Active moms define corporate social responsibility. Public Relat. Rev. 2008, 34, 343-350. [CrossRef]

5. Kim, M.; Yin, X.; Lee, G. The effect of CSR on corporate image, customer citizenship behaviors, and customers' long-term relationship orientation. Int. J. Hosp. Manag. 2020, 88, 102520. [CrossRef]

6. Kraus, S.; Rehman, S.U.; García, F.J.S. Corporate social responsibility and environmental performance: The mediating role of environmental strategy and green innovation. Technol. Forecast. Soc. Chang. 2020, 160, 120262. [CrossRef]

7. Orazalin, N.; Baydauletov, M. Corporate social responsibility strategy and corporate environmental and social performance: The moderating role of board gender diversity. Corp. Soc. Responsib. Environ. Manag. 2020, 27, 1664-1676. [CrossRef]

8. Lee, S.; Seo, K.; Sharma, A. Corporate social responsibility and firm performance in the airline industry: The moderating role of oil prices. Tour. Manag. 2013, 38, 20-30. [CrossRef]

9. Kim, J.S.; Song, H.; Lee, C.-K.; Lee, J.Y. The impact of four CSR dimensions on a gaming company's image and customers' revisit intentions. Int. J. Hosp. Manag. 2017, 61, 73-81. [CrossRef]

10. Carroll, A.B. The four faces of corporate citizenship. Bus. Soc. Rev. 1998, 100, 1-7. [CrossRef]

11. Cesar, S.; Jhony, O. Corporate Social Responsibility supports the construction of a strong social capital in the mining context: Evidence from Peru. J. Clean. Prod. 2020, 267, 122162. [CrossRef]

12. Bourdieu, P. The Forms of Capital. (1986). In Cultural Theory: An Anthology; Wiley-Blackwell: Hoboken, NJ, USA, $2011 ;$ pp. 81-93.

13. Belliveau, M.A.; O'Reilly, C.A., III; Wade, J.B. Social capital at the top: Effects of social similarity and status on CEO compensation. Acad. Manag. J. 1996, 39, 1568-1593.

14. Burt, R.S. The contingent value of social capital. Adm. Sci. Q. 1997, 42, 339-365. [CrossRef]

15. Hollenbeck, J.R.; Jamieson, B.B. Human capital, social capital, and social network analysis: Implications for strategic human resource management. Acad. Manag. Perspect. 2015, 29, 370-385. [CrossRef]

16. Methot, J.R.; Rosado-Solomon, E.H.; Allen, D.G. The network architecture of human captial: A relational identity perspective. Acad. Manag. Rev. 2018, 43, 723-748. [CrossRef]

17. Coleman, J.S. Social capital in the creation of human capital. Am. J. Sociol. 1988, 94, S95-S120. [CrossRef]

18. Huggins, R.; Johnston, A.; Thompson, P. Network capital, social capital and knowledge flow: How the nature of interorganizational networks impacts on innovation. Ind. Innov. 2012, 19, 203-232. [CrossRef]

19. Yan, Y.; Guan, J. Social capital, exploitative and exploratory innovations: The mediating roles of ego-network dynamics. Technol. Forecast. Soc. Chang. 2018, 126, 244-258. [CrossRef]

20. Galunic, C.; Ertug, G.; Gargiulo, M. The positive externalities of social capital: Benefiting from senior brokers. Acad. Manag. J. 2012, 55, 1213-1231. [CrossRef] 
21. Zhao, Y.; Feng, T.; Shi, H. External involvement and green product innovation: The moderating role of environmental uncertainty. Bus. Strategy Environ. 2018, 27, 1167-1180. [CrossRef]

22. Lynch, P.; O'Toole, T.; Biemans, W. Measuring involvement of a network of customers in NPD. J. Prod. Innov. Manag. 2016, 33, 166-180. [CrossRef]

23. Zhao, Y.; Zhang, X.; Jiang, W.; Feng, T. Does second-order social capital matter to green innovation? The moderating role of governance ambidexterity. Sustain. Prod. Consum. 2021, 25, 271-284. [CrossRef]

24. Tavassoli, M.; Saen, R.F. Predicting group membership of sustainable suppliers via data envelopment analysis and discriminant analysis. Sustain. Prod. Consum. 2019, 18, 41-52. [CrossRef]

25. Weber, C.; Kratzer, J. Social entrepreneurship, social networks and social value creation: A quantitative analysis among social entrepreneurs. Int. J. Entrep. Ventur. 2013, 5, 217-239. [CrossRef]

26. Chae, S.; Choi, T.Y.; Hur, D. Buyer power and supplier relationship commitment: A cognitive evaluation theory perspective. J. Supply Chain Manag. 2017, 53, 39-60. [CrossRef]

27. Holzner, B.; Wagner, M. Green Innovation and Profitability: The Moderating Effect of Environmental Uncertainty. Acad. Manag. Proc. 2019, 2019, 12337. [CrossRef]

28. Khan, A.; Chen, C.-C.; Lu, K.-H.; Wibowo, A.; Chen, S.-C.; Ruangkanjanases, A. Supply Chain Ambidexterity and Green SCM: Moderating Role of Network Capabilities. Sustainability 2021, 13, 5974. [CrossRef]

29. March, J.G. Exploration and exploitation in organizational learning. Organ. Sci. 1991, 2, 71-87. [CrossRef]

30. Liu, N.; Guan, J. Policy and innovation: Nanoenergy technology in the USA and China. Energy Policy 2016, 91, 220-232. [CrossRef]

31. Dai, J.; Cantor, D.E.; Montabon, F.L. How environmental management competitive pressure affects a focal firm's environmental innovation activities: A green supply chain perspective. J. Bus. Logist. 2015, 36, 242-259. [CrossRef]

32. Dragu, I.-M.; Tiron-Tudor, A. Integrating best reporting practices for enhancing corporate social responsibility. In Corporate Social Responsibility in the Global Business World; Springer: Berlin/Heidelberg, Germany, 2014; pp. 27-47.

33. Porter, M.E.; Kramer, M.R. The link between competitive advantage and corporate social responsibility. Harv. Bus. Rev. 2006, 84, 78-92. [PubMed]

34. Windsor, D. Corporate Social Responsibility: A Theory of the Firm Perspective: Some Comments. Acad. Manag. Rev. 2001, 26, 502-504.

35. Idowu, S.O.; Dragu, I.-M.; Tiron-Tudor, A.; Farcas, T.V. From CSR and sustainability to integrated reporting. Int. J. Soc. Entrep. Innov. 2016, 4, 134-151. [CrossRef]

36. Burt, R.S. The network structure of social capital. Res. Organ. Behav. 2000, 22, 345-423. [CrossRef]

37. Zhao, L.; Liang, C.; Gu, D. Mobile social media use and trailing parents' life satisfaction: Social capital and social integration perspective. Int. J. Aging Hum. Dev. 2021, 92, 383-405. [CrossRef]

38. Bellamy, M.A.; Ghosh, S.; Hora, M. The influence of supply network structure on firm innovation. J. Oper. Manag. 2014, 32, 357-373. [CrossRef]

39. Vveinhardt, J.; Andriukaitiene, R.; Cunha, L.M. Social capital as a cause and consequence of corporate social responsibility. Transform. Bus. Econ. 2014, 13, 483-505.

40. Weisband, E. The virtues of virtue: Social capital, network governance, and corporate social responsibility. Am. Behav. Sci. 2009, 52, 905-918. [CrossRef]

41. Degli Antoni, G.; Portale, E. The effect of corporate social responsibility on social capital creation in social cooperatives. Nonprofit Volunt. Sect. Q. 2011, 40, 566-582. [CrossRef]

42. Melay, I.; Kraus, S. Green entrepreneurship: Definitions of related concepts. Int. J. Strateg. Manag 2012, 12, 1-12.

43. Pekovic, S.; Vogt, S. The fit between corporate social responsibility and corporate governance: The impact on a firm's financial performance. Rev. Manag. Sci. 2020, 15, 1095-1125. [CrossRef]

44. Xiang, C.; Chen, F.; Jones, P.; Xia, S. The effect of institutional investors' distraction on firms' corporate social responsibility engagement: Evidence from China. Rev. Manag. Sci. 2020. [CrossRef]

45. Galbreath, J. Drivers of corporate social responsibility: The role of formal strategic planning and firm culture. Br. J. Manag. 2010, 21, 511-525. [CrossRef]

46. Vallaster, C.; Kraus, S.; Kailer, N.; Baldwin, B. Responsible entrepreneurship: Outlining the contingencies. Int. J. Entrep. Behav. Res. 2019, 25, 538-553. [CrossRef]

47. Melay, I.; O’Dwyer, M.; Kraus, S.; Gast, J. Green entrepreneurship in SMEs: A configuration approach. Int. J. Entrep. Ventur. 2017, 9,1-17. [CrossRef]

48. McWilliams, A.; Siegel, D. Corporate social responsibility and financial performance: Correlation or misspecification? Strateg. Manag. J. 2000, 21, 603-609. [CrossRef]

49. Zhou, G.; Zhang, L.; Zhang, L. Corporate social responsibility, the atmospheric environment, and technological innovation investment. Sustainability 2019, 11, 481. [CrossRef]

50. Javeed, S.A.; Latief, R.; Jiang, T.; San Ong, T.; Tang, Y. How environmental regulations and corporate social responsibility affect the firm innovation with the moderating role of Chief executive officer (CEO) power and ownership concentration? J. Clean. Prod. 2021, 308, 127212. [CrossRef]

51. Shahzad, M.; Qu, Y.; Javed, S.A.; Zafar, A.U.; Rehman, S.U. Relation of environment sustainability to CSR and green innovation: A case of Pakistani manufacturing industry. J. Clean. Prod. 2020, 253, 119938. [CrossRef] 
52. Kim, H.L.; Rhou, Y.; Uysal, M.; Kwon, N. An examination of the links between corporate social responsibility (CSR) and its internal consequences. Int. J. Hosp. Manag. 2017, 61, 26-34. [CrossRef]

53. Anderson, J.C.; Gerbing, D.W. Structural equation modeling in practice: A review and recommended two-step approach. Psychol. Bull. 1988, 103, 411. [CrossRef]

54. Hulland, J. Use of partial least squares (PLS) in strategic management research: A review of four recent studies. Strateg. Manag. J. 1999, 20, 195-204. [CrossRef]

55. Petter, S.; Straub, D.; Rai, A. Specifying formative constructs in information systems research. MIS Q. 2007, 31, 623-656. [CrossRef]

56. Chin, W.W.; Marcolin, B.L.; Newsted, P.R. A partial least squares latent variable modeling approach for measuring interaction effects: Results from a Monte Carlo simulation study and an electronic-mail emotion/adoption study. Inf. Syst. Res. 2003, 14, 189-217. [CrossRef]

57. Hair, J.F., Jr.; Sarstedt, M.; Hopkins, L.; Kuppelwieser, V.G. Partial least squares structural equation modeling (PLS-SEM): An emerging tool in business research. Eur. Bus. Rev. 2014, 26, 106-121. [CrossRef]

58. Preacher, K.J.; Hayes, A.F. SPSS and SAS procedures for estimating indirect effects in simple mediation models. Behav. Res. Methods Instrum. Comput. 2004, 36, 717-731. [CrossRef]

59. Bagozzi, R.P.; Yi, Y.; Phillips, L.W. Assessing construct validity in organizational research. Adm. Sci. Q. 1991, 36, 421-458. [CrossRef]

60. Hair, J.F., Jr.; Hult, G.T.M.; Ringle, C.; Sarstedt, M. A Primer on Partial Least Squares Structural Equation Modeling (PLS-SEM); Sage Publications: Thousand Oaks, CA, USA, 2016.

61. Tenenhaus, M.; Vinzi, V.E.; Chatelin, Y.-M.; Lauro, C. PLS path modeling. Comput. Stat. Data Anal. 2005, 48, 159-205. [CrossRef]

62. Wetzels, M.; Odekerken-Schröder, G.; Van Oppen, C. Using PLS path modeling for assessing hierarchical construct models: Guidelines and empirical illustration. MIS Q. 2009, 33, 177-195. [CrossRef]

63. Cropanzano, R.; Anthony, E.L.; Daniels, S.R.; Hall, A.V. Social exchange theory: A critical review with theoretical remedies. Acad. Manag. Ann. 2017, 11, 479-516. [CrossRef]

64. Kim, K.K.; Ryoo, S.Y.; Jung, M.D. Inter-organizational information systems visibility in buyer-supplier relationships: The case of telecommunication equipment component manufacturing industry. Omega 2011, 39, 667-676. [CrossRef]

65. Ferasso, M.; Beliaeva, T.; Kraus, S.; Clauss, T.; Ribeiro-Soriano, D. Circular economy business models: The state of research and avenues ahead. Bus. Strategy Environ. 2020, 29, 3006-3024. [CrossRef] 